\title{
Ssciendo
}

Ethics \& Bioethics (in Central Europe), 2020, 10 (3-4), 146-154

DOI:10.2478/ebce-2020-0020

\section{Ethical aspects of the non-romantic thinking of Jonáš Záborský and Štefan Launer}

\author{
Pavol Krištof ${ }^{1}$
}

\begin{abstract}
The paper focuses on the thinking of Jonáš Záborský (1812-1876) and Štěpán Launer (1821-1851), which were marginalized in Slovak national-forming thinking. Emphasis is placed on the comparison between non-romantic nationalism and Štúr's ethnic enthusiasm. Attention is paid to the value of their thinking, which can be analyzed in the context of reflections in the role of cultural identity in Štúr's conception of culture and its place in relation to European cultural and civilizational affiliation. At the same time, the critique of romantic thinking draws attention to the issue of the responsibility of nation-forming elites for the concept of civic development, which holistically approaches social change. Launer's and, partly Záborský's thinking draws attention to the dangers associated with the romantic search for ethnocultural specifics, which may result in the questioning the importance of civil liberties and Western cultural and civilizational affiliation.
\end{abstract}

Keywords: responsibility, nation, nationalism, culture, institutionalization, romanticism, enthusiasm

\section{Introduction}

While the national principle did not play a more relevant role in pre-industrial societies, political tendencies aimed at increasing cultural homogeneity and the associated pressures on cultural assimilation did not have a significant impact (Gellner, 1983, p. 63). This principle became significant only in social modernization, linked to a specific type of standardized culture capable of solving modern organizational structures' tasks. As a result, disputes over the concepts of official and language of instruction come to the fore, which were critical factors in the standardization of political and administrative structures in multiethnic societies, such as Hungary in $19^{\text {th }}$ century. ${ }^{2}$ Nationalism was an accompanying phenomenon of these structural changes in society. From this point of view, the national revivalists' role can also be interpreted in the context of social change, which have redefined collective identities and the associated loyalty to political institutions (Rusnák, 2019, pp. 190-192).

Ethnic enthusiasm, which was characterized by an emotional quality of thought and defense of the nation in the spirit of moral values, played an essential role in clashes between rival conceptions of nationalism. The distinguishing criterion between these concepts was the political-territorial or ethnocultural aspect (Pichler, 1998, pp. 111-112), while the participants in the modernization dispute, as bearers of ideas, interpreted this tension as a clash between patriotism and cultural equality. Through emotional perception, a low level of national awareness was interpreted as indifference to the process of ethnocultural emancipation. It can be said that this question had a moral character for national elites, because they understood the growth of national consciousness in the sense of the need to change the value orientation and the moral uplifting of society.

\section{Záborský's non-romantic thinking}

Although in the pre-revolutionary period, the similarities between Štúr and Záborský's philosophical conceptions can be stated, even at this time, their approaches to understanding the role of the people and elites in the national-forming process differed. Záborský's liberal, civic-national program was formulated as cultural and enlightening, and so it has a

\footnotetext{
${ }^{1}$ Trnava University (Slovakia); pavol.kristof@truni.sk

${ }^{2}$ The text describes Hungary as part of the multi-ethnic Habsburg monarchy. It is therefore not a Hungarian nation state that was established after the World War I.
} 
predominantly national-emancipatory character. A specific feature of his thinking, which distinguishes it from the prevailing current of romantic nationalism, was his non-romantic, critical approach to the nation-forming process. He was also critical of Štúr's ethical romanticism of revolutionary action, ${ }^{3}$ which puts exaggerated hopes in the "great deeds" and heroic actions through which radical social change occurs (Pichler, 1998, p. 108). According to Záborský, the nation-building effort cannot be led by the ambition to pursue romantic ideals, regardless of specific social and historical circumstances. Decision-making should be based on knowledge of social reality and national needs. In his practical morality, Záborský emphasized the critical approach based on common sense (obecný rozum), which he contrasted with romantic thinking and Hegel's philosophy when he wrote: "I am for life, reality and common sense" (Záborský, 1989, p. 328).

Záborský, like Ján Kollár, understood the nation as a natural community of speech, culture and customs (Záborský, 1988, p. 184). Based on the idea of Slavic reciprocity, he defined national identity in the broader context of a tribally differentiated Slavic nation (Maxwell, 2009, s. 96). However, unlike Ján Kollár, he did not necessarily consider the process of spreading national consciousness to be apolitical and did not completely rule out the possibility of forming a national identity through political institutions. Like Kollár, Záborský also warned against an orientation that would lead to the establishment of nationalism of small nations and an emphasis on own national individuality, which would lead to the establishment of provincial culture.

We can say that Jonáš Záborský complemented the ethnic enthusiasm influenced by Kollár with a civic ethos, thus connecting love for the nation with the need for civic unity and social understanding. Therefore, just as he refused to reduce social change to a top-down process, he did not limit public life to impersonal and formal relationships. Based on this knowledge, it can be stated that he understood patriotism in the sense of an acceptable form of coexistence of mature and equal citizens. A well-organized society cannot function if there is no unity among its citizens. Záborský did not assume that it was possible to run social changes and shape civil society without informal, friendly relations between confident and educated citizens. At the same time, he reformulated the understanding of patriotism, as defined by Kollár, out of love, or loyalty to the country, to cohesion among citizens. However, such relationships are only possible if the citizens are truly equal, including in the field of culture and speech. Without equality, the preconditions for civil liberties cannot be developed or kept. At the same time, Záborský considered civic unity crucial for the country's democratization and political development (Záborský, 1853, p. 188).

Based on the above, he confronted the people's romantic idealization with the everyday reality of social and economic passivity, illiteracy, and cultural backwardness. ${ }^{4} \mathrm{He}$ thought about their origins in demoralization and cultural decline caused by the absence of rights. Here he identified the causes of slavish servility, weakness, loss of interest in higher goals, and alcoholism, which the lower classes of the population were subjected to (Záborský, 1851, p. 165). Based on this fact, he stated the loss of value orientation. It could be said that the moral improvement of the people should be a prerequisite for national emancipation (Kalajtzidis, 2019, p. 91).

According to Záborský, the process of expanding civil rights cannot be carried out regardless of pre-political, i.e., cultural, educational and economic preconditions. As Záborský also states; the practical application of civil liberties in public life cannot be expected without cultural uplifting and the acquisition of civic virtues (Pichler, 1998, p. 107). Therefore, he considers the

\footnotetext{
${ }^{3}$ Gluchman draws attention to a certain "non-revolutionary" aspect of his thinking when he states in this connection that Záborský rejects disobedience to the nobility. According to him, the citizen should voluntarily accept the lordship and submit to it (Gluchman, 2012, p. 24).

${ }^{4}$ According to Pichler, Záborský distinguished between the people as a nation and the people as a specific social class (Pichler, 1998, p. 101).
} 
change of individual moral attitudes to be an integral part of transforming the traditional into a prosperous civil society. According to Záborský, society's democratization should be accompanied by a change in the serf mentality into the civic culture. At the same time, this change requires a change in value orientation, a change in serf passivity into civic engagement. In this context, he saw the importance of the role of elites, in particular the lower nobility and clergy (Kalajtzidis, 2019, p. 90). In this case, too, he emphasized the role of socio-educational and folk education work focused on acculturation. ${ }^{5} \mathrm{He}$ also emphasizes the importance of gradual and purposeful action aimed at changing established patterns of behaviour.

He considered the persistent serf mentality to be one of the manifestations of this freedom's inability in public and economic life. At the same time, he states the predominant orientation towards pursuing personal benefits and interests. Therefore, he wrote about the need to change the value orientation. Its goal can be to acquire practical virtues and confident attitudes. Záborský considered general demoralization to be a remnant of the absence of rights among the lower strata of the population (Záborský, 1989, p. 141). The unfree mentality, together with the loss of national consciousness, which Záborský understood as a concrete manifestation of value orientation, influences the most severe social issues. Therefore, without the development of civic virtues, democratic principles in everyday life cannot be expected. Thus, the success of democratization affects the active participation of educated and confident individuals in public life. Thus, the goal of changes should be not only the formation of national identity, but also moral values and the acquisition of confident civic attitudes.

Likewise, by changing the orientation, as Záborský mentioned, the connecting ability of individuals to take the initiative and responsibility for public life also changes. Therefore, the process of nation formation requires a particular formation of autonomous cultural and public institutions. Thus, Záborský emphasizes the importance of social transformation in the area of political or legislative reforms and social relations that change individual attitudes. He was looking for differences between modern and traditional society in value orientation - national and civic ethos. Záborský points to the tension between a specific political organization's nature and civic emancipation and individual development. It also had consequences in terms of the organization and stability of social institutions. Without adequate civic engagement, the stability of a democratic order is unsustainable. Thus, civic organizations cannot perform without the essential activity of all strata of society (Záborský, 1853, p. 290).

\section{Záborský's concept of enthusiasm}

Záborský's enthusiasm can be considered problematic and atypical because it was seemingly at odds with his non-romantic nationalism. As mentioned above, his love for the nation was not blind to social ills. Therefore, he does not show a simple dichotomy of the nation and external threats (Záborský, 1956, s. 278). He formulated his understanding of national feeling mainly in the speech entitled Ohavnost odrodilosti mezi námi Slováky [The abomination of denationalization among us Slovaks], published together with the collection Žehry [Complaints] (Záborský, 1851). In it, he defined enthusiasm not only in terms of the binding demand for love for the nation, but, like Ján Kollár, defended it as a moral demand to spread and promote this feeling. Simultaneously, based on Kollár's conception, Záborský considered the effort mentioned above to elevate the nation to be a moral obligation. He identified a keen interest in national interests with an orientation towards the common good beyond the focus on private and individual interests (Záborský, 1851, pp. 180-181). Like Kollár, he also considered indifference to the nation as a manifestation of greed, limitation, corporeality, but also a loss of

\footnotetext{
${ }^{5}$ I use the terms political, socio-educational and folk educational work in the sense used by Elena Várossová in her work Slovenské obrodenecké myslenie v kontexte prakticizmu Ludovita Štúra [Slovak revivalist thinking in the context of Ludovit Štúr's practicism] (Várossová, 1963, p. 45).
} 
interest in higher goals (Záborský, 1853, p. 179). Záborský, thus, attributed the role of selfsacrificing and altruistic elites to ethnic enthusiasts (Záborský, 1989, p. 327). Orientation to the nation was to elevate its members beyond concern for their own needs and direct them to higher goals. He saw the spread of national consciousness and assimilation as an extreme manifestation of the relationship of individuals towards their nation (Záborský, 1989, p. 179). At the same time, he emphasized the moral dimension of the loss or change of national identity (Záborský, 1989 , p. 298). Although he considered its purposeful change to be a moral failure, at the same time, it was a systematic way of gaining social benefits in Hungary at the time. He observed its causes in general moral decay and was not interested in culture and any higher goals.

However, Záborský's understanding of nationality as a moral category led him, like Kollár, to reject the possibility of choosing between a national and a civic principle. Even Záborský did not put a well-organized municipality and individual choice on one level. ${ }^{6}$ It was the work and influence of the renegades, as he called those who, for particular personal reasons, changed their identity, that he considered more dangerous for the Slovak nation than the influence of external power factors (Záborský, 1851, p. 124).

\section{Launer's non-romantic concept}

Štěpan Launer (1821-1851) was an author with a unique position in the Slovak national revival context due to his non-romantic concept. We could say that his solution to the dilemma of Slavdom or Europeanism is, in many ways, similar to today's geopolitical debates in Slovakia. Although he was a student of L'udovít Štúr, he sharply rejected his romantic revival program. However, it must be said that the savagery of his politically engaged pamphlets surpassed the contributions of other authors arguing about the Czech-Slovak literary schism (Pišút, 1949, p. 29). He earned the title of traitor to the nation for criticising Štúr's romantic nationalism and supporting the Hungarian revolution.

It can be said that the above-mentioned evaluation conclusions of the Štúrian movement were based on Kollár's view of the importance of ethnic enthusiasm. Ján Kollár, who, together with Záborský and Launer, was an opponent of the Štúrian national-forming program, considered the absence of national consciousness, or indifference to national life, to be a moral failure. At the same time, he attributed ethnic enthusiasm to the role of one of the main virtues that was supposed to complement the faith (Kollár, 1892, p. 4). Therefore, while he associated enthusiasm with an orientation towards universal values, he considered patriotism as a political principle to be artificial, focused primarily on partial goals. In Kollár's conception, the value of the nation, with its universal focus, outweighed particular political interests. At the same time, Kollár considered patriotism as a principle to be unstable and accidental, because it was to be as variable as political loyalty, which changes along with the change of citizenship.

Although Launer's philosophical conception showed certain ideological parallels with another "national sinner", Jonáš Záborský, their thinking differed not only in the starting points, especially in the evaluation of Hegel's philosophy, but also in the relationship between civic and national principles. However, Launer, like Záborský, emphasized the importance of political modernization and the expansion of political rights and freedoms, considering the issue of democratization to be inseparable from the expansion of education and traditional culture (Haydanka, 2014). For Launer, it was an enthusiasm that inspired his contemporaries to a nation he considered uneducated and culturally underdeveloped. ${ }^{7}$ Like Záborský, he did not see a path

\footnotetext{
${ }^{6}$ Gellner writes of a great confrontation between rationalist individualism and romantic communitarianism. He combines individualism with the protection and enforcement of civil society rules. At the same time, it combines it with ethics that gives a good social order, which maximizes citizen satisfaction to one level (Gellner, 1998, p. $85)$.

${ }^{7}$ Marcel Martinkovič states that Ján Palárik, unlike Launer, emphasized the connection between the civic and national emancipation of the Slovak-speaking population (Martinkovič, 2013, p. 43).
} 
in the national emancipation of the illiterate (Kalajtzidis, 2019, p. 90). Launer did not see value implications in cultural identity and we could say that, unlike Kollár, he considered loyalty to the constitution a virtue. At the same time, he denied that belonging to a linguistically and culturally defined social group would constitute a moral obligation for the individual that should affect loyalty to the state or affect compliance with the law. Similarly, he disagreed with the opinion that cultural identity should impact on the possibility of shaping civic individualism, or another, albeit more abstract, form of social cohesion.

For this reason, he was a sharp critic of Štur's concept focused on national emancipation. Thus, in the eyes of the followers of Štur, Launer betrayed the nation because he did not look for its peculiarity in folk culture but appreciated the importance of European education and the Hungarian constitution. It could be said that Launer realized that it was the issue of the formation of national identity, together with enthusiasm, that complicated the formation of civil society by introducing a contradiction between the polis and the ethnos (Pichler, 2006, p. 584). He did not attribute the value of nationality until it was enriched by science and culture. Although he understood national identity as natural, he also stated the need for its spirituality, cultivation and development (Launer, 1847a, p. 209). Therefore, it can be said that he considered education and civic competence to be more relevant values than the peculiarity of the raw nature of undeveloped and uncultivated ethnicity (Launer, 1847b, p. 7).

\section{The issue of enthusiasm - politics and culture}

It could be said that Launer also differed from his contemporaries in that he did not find politicum in the value of national culture when (Pišút, 1949, p. 29), unlike Záborský, he preferred patriotism to the ethnic principle. The same is true of liberal ideas and violent cultural assimilation, to which his contemporaries attributed critical relevance, he remained indifferent (Pichler, 2004, p. 704). Based on Kollár's narrative, in which love for the nation was to have moral validity, Launer, according to his contemporaries, including Záborský, sacrificed liberalism to the demand for cultural equality of non-Hungarian ethnic groups. Simultaneously, unlike Záborský, he considered civil liberties and the Hungarian constitution to be of higher value than cultural pluralism or linguistic equality. At the same time, he warned of the risks of a romantic search for national specifics, which he considered politically and historically irresponsible. At the same time, he anticipated the fact that Štur's thinking in this way would lead to the questioning of the modern criteria of progress, liberalism and Western culturalcivilizational principles. Although, like Kollár, he stated that Slovaks have their origins in humanity and Slavdom, he preferred European cultural-civilizational affiliation to ethnocultural identity, which he considered more important than awareness of a common origin uniting Slavs (Launer, 1847a, p. v).

For these reasons, Launer's concept was characterized by an orientation towards social development, culminating in a constitutional and liberal arrangement. Based on Hegel's philosophy, he considers nations to be instruments through which the world spirit works (Launer, 1847a, p. v). However, in contrast to the romantic concept, Launer rejected the idea of a particular historical mission of the Slavs, which would go beyond the framework of the value orientation of Western culture, philosophy and constitutionalism. The historical task of Slavdom is to be "supplement the history of the Indo-European peoples" (Launer, 1847a, p. 110). The task of every great nation is to transform the general humanistic content into a specific national form. At the same time, like Záborský, progress in the field of politics is, according to him, conditioned by development in all areas of social life. Therefore, the stimulus for social development cannot draw inspiration from folk culture, but its institutionalization and development of science (Pichler, 2004, p. 704). We could say that Launer differed from his 
contemporaries precisely in that he considered education more important for the development of value orientation than enthusiasm for folk culture. That is why Launer warns against the romantic search for a primordial national specificity. He does not consider such adventures as responsible.

For this reason, Launer questioned Štúr's moral motivation, because, in his opinion, his conception should lead to a departure from the standards of European education and culture to a trajectory that leads to a dead end, which can result in a loss of value orientation. It should be appreciated that, in this way, he foresaw the development of Štur's thinking, which characterizes the work of Slovanstvo a svet buducnosti [Slavism and the world of the future] (Štúr, 1993). We could state that Launer was opposed to what Gellner describes as Herderian protectionism of folk cultures (Gellner, 1997, p. 35). According to Launer, it is education and traditional culture that give individuals a real identity. He firmly rejects the preference for inanimate and uncultivated folkiness over the development of civil liberties, ${ }^{8}$ Western culture and education, but he considers them harmful. (Launer, 1847b, p. 6). It can be said that Launer does not demand nationality but Western cultural-civilizational affiliation. At the same time, he differs from Záborský in this particular question, whose attitudes are critical of the Romantic movement, but a critical but still national enthusiasm characterizes his thinking.

Launer viewed the process of social development and democratization similarly. Liberalism and constitutionalism represent reform in his view, i.e., restoration of the state and its laws. Although he espoused the ideas of liberalism, it is not known to be based on Mill, Locke, Montesquieu, but rather the influence of Hegel and Luther's thinking is noticeable (Gbúrová, 2019 , pp. 50, 70). Freedom and the expansion of civil rights depend on the quality of practical political life: acquiring modern civic competencies in practice. This is to be reflected in the development of constitutional life. Therefore, individual countries' laws should be the most obvious manifestation of the quality of education and individual nations' spirit. At the same time, he did not consider the existence of constitutional life only as a concrete manifestation of legality, but he also understood it as an expression of spiritual and moral effort. The nation's spirit is manifested in the knowledge of man's value, which is transformed into laws. Thus, the constitutions of individual countries articulate the spirit and determine a specific way of understanding the individual and his position in society. Launer understood constitutionalism more broadly, as it reflected the level of civic and interpersonal relations, civil law, and the development of religious life. The same can be said of the value of man in the case of non-free states. Absolutism is, thus, a manifestation of a low level of civic, moral and religious development. It is the development of education that impacts on the implementation of the liberal order and more humane laws. Therefore, for Launer, those nations living in absolutist states were spiritually underdeveloped or incapable of exercising political rights and freedoms. Thus, they accepted the authoritarian "education" of other nations or absolutist or despotic rulers.

\section{The historical concept of Slavdom}

It is also worth noting Launer's view of the importance of Europe for the Slavs, which again concerns the responsibility of romantic elites for the formation of the nation and its value orientation. The historical task of the Slavs is not to discover a new authentic Slavic culture but to accept modern European cultural and civilizational impulses. He understood history as a process leading to civic emancipation from despotic forms to liberal states represented by Western European nations (Várossová, 1988, p. 699). At present, Launer has recognized four

\footnotetext{
${ }^{8}$ Launer did not even emphasize the importance of national emancipation in the issue of expanding education, as it was in the case of Ján Palárik. Marcel Martinkovič writes more about Palárik’s thinking and different strategies in Slovak political thought (Martinkovič, 2008, p. 893).
} 
prototypes Italian, French, English and German, which represent the whole of Europe. He peculiarly assigns Slavic nations to the above prototypes to transform these principles into the Slavic environment. Based on cultural-civilizational development, he considers Central European Slavs to be more developed than Eastern ones. However, their task is to mechanically imitate European cultural and scientific patterns and reformulate them and transform them into a Slavic form. At the same time, he considered Russia to be an independently developing cultural entity, the potential modernization of which he combines with the acceptance of Western culture and education (Launer, 1847a, p. 118).

Launer's view that he identifies Slovaks as part of the Czechoslovak tribe with the German philosophical-theoretical spirit can be considered a certain idealization or tendency. The role and historical mission of the Slovaks is to strengthen the German spirit (Launer, 1847a, p. 164). At the same time, Launer criticized Štúr's romantic interpretation of history, which he considered as morally irresponsible as the search for national specifics that would not respect European values. At the same time, Launer criticized Štúr's romantic interpretation of history. According to Launer, Slovak identity does not need to be invented. Slovaks already have their peculiarity, but different from the one formulated by Štúr. It, in particular, belongs to Slavism and Europe - as a Western cultural-civilizational paradigm. Launer thus emphasized the role of civilizational competence, which is manifested in the sharing of Western culture. He defined Slovak identity through cultural, political and religious affiliation with the West when he stated that where European orientation was accepted, it is impossible to speak of historical passivity. According to Launer, Slovaks proved their cultural competence as part of the Czechoslovak tribe and politically as Hungary's inhabitants, whose constitutionalism proves their civic competence. According to Launer, belonging to Protestantism also refutes Štúr's idea of the "thousand-year beauty sleep".

Unlike Štúr and Záborský, in his historical interpretations, Launer does not romantically return to Great Moravia, but by rejecting negative historicism, he defended the active participation of Slovaks in Hungarian history. ${ }^{9}$ At the same time, he assessed Slovaks' historical-creating competence in terms of participation in Hungarian history, the creator of which was not only one nation. At the same time, he stated the affinity of Hungarian and Czech political and cultural developments. Therefore, the history of the Bohemian and the Hungarian kingdom cannot be interpreted without regard to common political and cultural ties (Launer, 1847a, p. 133). Launer tried to demonstrate the affinity of the Slovaks for the Hussite and Brethren movement, which he, to some extent, idealized when he regarded it as the original Czechoslovak Protestant religion and national democratic movement aimed at liberation from authoritarianism and Catholic dogmatism. At the same time, he saw the Hussite movement as a pioneer of the reform movement and democratization. On this basis, he identified the Czechoslovak spirit with liberal and Protestant principles (Maxwell, 2009, p. 132). It was Protestantism that became, for him, the highest degree of the spirit of the time in Europe (Gbúrová, 2019, p. 50). According to Launer, Protestantism itself must be understood in the broader context of social and cultural change, when, like Hegel, he combined religious reform with the reform of the state, because as Protestantism, he understood not only the renewal of the church but also the reform of the state, legislation, art, science and philosophy (Hegel, 2001, p. 67).

\section{Conclusion}

Although the thinking of Jonáš Záborský and Štěpán Launer was marginalized in the Slovak discourse, in many ways, it paints a picture of the development of national identity and culture.

\footnotetext{
${ }^{9}$ The Kingdom of Hungary was a multi-ethnic state in the Carpathian Basin from 895/896 to 1918. The territory of today's Slovakia was gradually incorporated into the kingdom from the $10^{\text {th }}$ to the $11^{\text {th }}$ century. It was a part of it until 1918 when Czechoslovakia was founded.
} 
At the same time, it completes the formation of a modern Slovak identity, which cannot be considered monolithic (Várossová, 1988, p. 697). While ethnic enthusiasm, as a passional way of thinking, played an essential role in the revolutionary national narrative in the context of the absence of cultural institutionalization, Jonáš Záborský and Štěpan Launer pointed out in their criticism that such views on the formation of national identity created a contradiction between polis and ethnos (Pichler, 2006, p. 584). This thinking did not allow for an individual choice between citizenship and national identity and left the responsibility for the decision to the representatives of national movements. Paradoxically, it was the national elites who were not united in defining cultural identity, which is why the responsibility of elites conceived in this way caused tension. Thus, ethnic enthusiasm did not imply the possibility of the formation of civic individualism but focused on the defence of collective rights. Although this type of thinking provided responsibility for the development and orientation to higher values to the representatives of nation-forming ideas, the emotional quality of thinking often led them to irreconcilable controversy and marginalization of opponents (Rusnák, 2013, p. 87).

The value of the non-romantic thinking of Záborský and Launer can also be seen in the context of current reflections on the role of cultural identity in the context of the Štur-Hurban conception of national culture and its place in European culture. At the same time, the critique of romantic thinking draws attention to the issue of the responsibility of nation-forming elites for the concept of civic development, which does not approach social change holistically and for cultural development and the role of modern European cultural-civilizational impulses for modern European cultural identity. Simultaneously, it can be stated that Launer's and, in part, Záborský's thinking draws attention to the threat associated with the romantic search for ethnocultural peculiarity, which may result in the questioning of the importance of civil liberties and Western cultural-civilizational affiliation.

\section{Acknowledgement}

The paper is the result of the solution of the KEGA project no. 008TTU-4/2019.

\section{References}

GELLNER, E. (1998): Language and solitude: Wittgenstein, Malinowski and the Habsburg Dilemma. Cambridge: Cambridge University Press.

GELLNER, E. (1997): Nationalism. London: Weidenfeld \& Nicolson.

GELLNER, A. (1983): Nations and nationalism. Ithaca: Cornell University Press.

GBÚROVÁ, M. (2019): Štefan Launer (1821-1851): kritik Štúrovej jazykovej modernizácie vizionár budúcnosti Slovanstva v Európe [Štefan Launer (1821-1851): Critic of Štúr's linguistic modernization, visionary of the future of Slavdom in Europe]. Bratislava: Veda.

GLUCHMAN, V. (2012): Podoby humanitného ideálu v slovenskom etickom myslení 19. storočia a prvej polovice 20. storočia [Forms of the humanitarian ideal in Slovak ethical thinking of the 19th century and the first half of the 20th century]. In: V. Gluchman (ed.): Etika na Slovensku (19. a 20. storočie) [Ethics in Slovakia (19th and 20th centuries)]. Prešov: FF PU, pp. 11-60.

HAYDANKA, Y. (2014). Democratic transit model in its theoretical and empirical dimensions. In: The Journal of V.N. Karazin Kharkiv National University, series Issues of Political Science, 1111, pp. 72-77.

HEGEL, G. W. F. (2001): The philosophy of history. Kitchener: Batoche Books.

LAUNER, Š. (1847a): Povaha Slovanstva, se zvláštním ohledem na spisovni řeč Čechů, Moravanů, Slezáki a Slováki̊ [The nature of Slavdom, especially from the perspective of the literary language of the Czechs, Moravians, Silesians and Slovaks]. Lipsko: Komise slovanského kníhkupectví.

LAUNER, Š. (1847b): Slowo národu swému [A word to my people]. B. Štiavnica: F. Lorber. 
KALAJTZIDIS, J. (2019): Etické a filozofické prvky v tvorbe Jonáša Záborského [Ethical and philosophical aspects of Jonáš Záborský's works]. In: V. Gluchman (ed.): Etika na Slovensku a v Európe (1751-1850) [Ethics in Slovakia and in Europe (1751-1850)]. Prešov: FF PU, pp. 79-92.

KOLLÁR, J. (1892): Nábožnost a národnost jako sestry [Religiousness and nationality as sisters]. Ružomberok: Karol Salva.

MARTINKOVIČ, M. (2013): Politické myslenie Novej školy. Občiansko-národný program Slovenských novin [The political thinking of the New School: Civic-national program of Slovak newspapers]. Bratislava: Filozofický ústav SAV.

MARTINKOVIČ, M. (2008): Ideové paralely a odlišné stratégie s slovenskom politickom myslení [Ideological parallels and different strategies with Slovak political thinking]. In: Filozofia, 63(10), pp. 892-900.

MAXWELL, A. (2009): Choosing Slovakia: Slavic Hungary, the Czechoslovak Language and Accidental Nationalism. London \& New York: I. B. Tauris Publishers.

PICHLER, T. (2006): Národ, národnosti, štát: O politike etnického entuziazmu [Nation, nationalities, state: On the politics of ethnic enthusiasm]. In: Historický časopis, 54(4), pp. 569590.

PICHLER, T. (2004): Slovanstvo ako európanstvo: Štěpan Launer a jeho predstava modernizácie [Slavdom as Europeanness: Stepan Launer and his idea of modernization]. In: Filozofia, 59(10), pp. 697-706.

PICHLER, T. (1998): Národovci a občania: O slovenskom politickom myslení v 19. storoči [Nationalists and citizens: On Slovak political thought in the 19th Century]. Bratislava: Veda. PIŠÚT, M. (1949): Renegát či Európan? (Mad'arská monografia o Štefanovi Launerovi) [Renegade or European? (Hungarian monograph on Stefan Launer)]. In: Tvorba, 8(2), pp. 2930 .

RUSNÁK, P. (2019): The sacred and the profane in Russian anthropology and philosophy. In: J. Feber, H. Hrehová \& P. Rusnák (eds.): Man between Sacrum and Profanum in Russian Philosophy in 20th Century. Berlin: Peter Lang Verlag, pp. 187-215.

RUSNÁK, P. (2013): Selected impacts of the dispute between liberalism and communitarianism in contemporary ethics and law. In: Ethics \& Bioethics (in Central Europe), 3(1-2), pp. 87-96.

ŠTÚR, L. (1993): Slovanstvo a svet budúcnosti [Slavism and the world of the future]. Bratislava: Slovenský inštitút medzinárodných štúdií.

VÁROSSOVÁ, E. (1988): Svojbytnost' Slovákov v Launerovej Povahe Slovanstva (1847) [The originality of Slovaks in Launer's Nature of Slavdom (1847)]. In: Filozofia, 43(6), pp. 697704.

VÁROSSOVÁ, E. (1963): Slovenské obrodenecké myslenie [Slovak revivalist thinking]. Bratislava: Vydavatel'stvo Slovenskej akadémie vied.

ZÁBORSKÝ, J. (1989): Dielo II. [Work II]. Bratislava: Tatran.

ZÁBORSKÝ, J. (1988): Dielo I. [Work I]. Bratislava: Tatran.

ZÁBORSKÝ, J. (1956): Listy Jozefovi Viktorinovi [Letters to Jozef Viktorin]. In: E. Lazar: Jonáś Záborský: Život - literárne dielo - korešpondencia [Jonáš Záborský: Life - Literary Work-Correspondence]. Bratislava: Slovenské vydavatel'stvo krásnej literatúry, pp. 253-322. ZÁBORSKÝ, J. (1853): Múdrost života ve chrámových řečich. Pro všecky roku cirkevního přiležitosti I. [The wisdom of life in temple speech: For all years of Church events, vol. I] Viedeň: Albert A. Venedikt.

ZÁBORSKÝ, J. (1851): Žehry, Básně a dvě reči [Complaints, Poems and two speeches]. Viedeň: Tiskárna Mechitaristů. 